\title{
Tobacco control policy-making in Portugal: vested interests or public health?
}

\author{
Sofia Ravara ${ }^{1,2}$, Hilson Cunh Filho ${ }^{2,3}$, Paula Lobato Faria ${ }^{4}$, Notercia Miranda ${ }^{2}$, Jose Manuel Calheiros ${ }^{1,2}$
}

\section{INTRODUCTION}

Tobacco use remains a threat to global health and socio-economic development ${ }^{1}$. In order to curb the tobacco epidemic, the World Health Organisation (WHO) developed the Framework Convention on Tobacco Control (FCTC), which aims to protect populations from tobacco consumption and exposure to tobacco smoke ${ }^{2}$. The FCTC binds its ratifying parties, such as the European Union (EU) and the EU Member States (MS), to implement evidence-based tobacco control (TC) policies ${ }^{2}$. Although FCTC policies are implementable at the EU and MS level, Europe still ranks first regarding smoking prevalence among $\mathrm{WHO}$ regions ${ }^{1}$

\section{PORTUGAL AND TOBACCO CONTROL}

Portugal, on which this article focuses, has low TC activity ${ }^{3}$. Notably, limited TC awareness and poor capacity building amongst healthcare professionals (HCPs), governments, policy makers and civil society, as well as the interference of the tobacco industry, are major barriers to FCTCimplementation ${ }^{4}$. The knowledge of tobacco industrytactics, aswellashealthimpactassessment, are crucial advocacy tools ${ }^{4-6}$. In Portugal, TC research on these aforementioned tools is limited, while HCPs' engagement and leadership in TC is poor, undermining potential capacity building and tobacco use denormalisation ${ }^{6-9}$.

An analysis of internal industry documents concerning Portugal and Spain reveals a detailed strategic plan to influence economic groups, the media, journalists /opinion leaders; governments, politicians/political parties; scientific societies; the public health community and health authorities ${ }^{10}$. Moreover, Portugal is among the countries of the WHO European region with industry sponsorship involving municipalities, culture, arts and music festivals, as well as social responsibility projects and charitable contributions ${ }^{11-13}$. Such activities are noted as effective ways to promote the social acceptance of the tobacco industry and interfere in policy-making ${ }^{4,14}$.

Currently, the EU has a window of opportunity to advance TC: the implementation of the Tobacco Products Directive (TPD $)^{15}$. The challenge now facing EU MS is its transposition into national legislation, effective enforcement and subsequent monitoring.

The weaknesses of loopholes in tobacco control policy-making are well documented ${ }^{4,16-17}$. Following FCTC ratification by Portugal in 2005, a new tobacco law was approved in 2007 and came into force in January $2008^{18}$. Cunha-Filho et al., using the case of the Portuguese 2007 tobacco legislation $^{18}$, discussed the complex interaction among the social actors that intervene in public health decision-making, underlining this practice as being far from transparent ${ }^{19}$. Prevailing vested interests indicate a forceful interference in policymaking leading to legal loopholes which promote exemptions and undermine the implementation and enforcement of TC legislations ${ }^{4,16,19-22}$.

Regarding the Portuguese TC legislation ${ }^{18}$, several authors report underfunding, poor implementation and enforcement; a lack of public health campaigns; limited HCPs' leadership and capacity building; inconsistent smoke-free policy support and non-assertiveness from health authorities, regardless of the robust scientific and legal evidence in its support ${ }^{8,19-22}$. While breaches and ineffective enforcement of the legislation were announced in the media, limited media coverage of NGOs' initiatives and media barriers to TC awareness are common ${ }^{19-20,22}$. Important public persons, who should be role models, were involved in ban breaches and were not fined ${ }^{19-}$ 20, 23-24. All these facts have undermined the effectiveness of the smoking ban ${ }^{19-20,22}$.

\section{PORTUGAL AND THE TPD}

In March 2013, following the decision of the parliamentary committee for European Affairs ${ }^{25}$,

\section{AFFILIATION}

1 Faculty of Health

Sciences, University of Beira Interior, Covilha, Portugal

2 Centre for Advocacy,

Treatment and

Reabilitation, NGO(CATR),

Lisbon, Portugal

3 Faculty of Social

Sciences and Humanities, NOVA University of Lisbon, Portugal

4 National School of Public Health, NOVA University of Lisbon, Portugal

CORRESPONDENCE TO Ravara S. Health Sciences Research Center, Faculty of Health Sciences,

University of Beira Interior, Av. Infante D. Henrique, 6200-506 Covilha, Portugal, sbravara@ fcsaude.ubi.pt

KEYWORDS

tobacco, health policy, legislation, Advocacy, tobacco industry, Framework Convention on Tobacco Control 
the Portuguese National Parliament unanimously approved a resolution against the TPD, claiming that it violates the subsidiary principle because its goals are not better pursued by an EU action than by internal measures ${ }^{25}$. Additionally, most Portuguese members of the European Parliament did not fully support the TPD. Several parliamentarians had demonstrated against packaging and other TPD measures, demanding for the need to protect the Azores' tobacco industry and stating that “... Portugal expressed its position by the members of the parliamentary committee for European affairs; they did not hide the need to protect somehow the tobacco industry ... This position is always conveyed by the national parliament whenever a new law is discussed in Europe .... The TPD interferes with national matters violating the principles of "subsidiarity" and "proportionality" .... and would have a negative economic impact which would not be curbed by the health gains ... some of the TPD measures are arbitrary and punitive; there is no indication that they reach the public health goals ${ }^{26-27}$.

The Portuguese government and policy-makers' arguments to reject the TPD were the same advocated by several tobacco companies which participated in a joint hearing by the parliamentary committee for European Affairs, the health committee and the economy and public works committee ${ }^{25}$. The interference of the tobacco industry in the national parliament counteracting the opinion of the Health Committee, targeting key parliamentarians in political parties and nonhealth committees and disseminating negative messages to the press regarding the legal consistence and enforcement of the TPD is well documented ${ }^{25-27}$.

In June 2013, at the Council of the EU, the representative of the Portuguese government declared the following legislative deliberations: "Portugal expresses reservations regarding the TPD ..." "...Portugal cannot accept the minimum dimensions of tobacco products packaging and labeling included in TPD...", and "... supports the introduction of health warnings occupying only $50 \%$ of the package ...." "banning menthol in tobacco products is excessive..." “...Portugal can only accept the traceability measures until the first trader..."28. In March 2014, Portugal approved the TPD, when the majority of the European Council had already voted in favor. It should be emphasised that decision-makers did not take into account the position of non-governmental organisations (NGOs') which struggled to promote support for a strong directive ${ }^{29}$, nor the multiple surveys which have shown that most Portuguese/ EU citizens support comprehensive smoke-free legislations and TPD measures ${ }^{30-31}$. During the TPD negotiations, the European Parliament witnessed the massive tobacco industry lobby that successfully delayed or undermined the adoption of comprehensive measures on packaging, flavoring and ecigarettes $^{32-34}$. The tobacco industry attempts to influence marketing regulation are extensively documented ${ }^{4,16-19,34-35}$. The key arguments employed are recurrent and relate to potential loss of jobs and other economical negative impacts; poor effectiveness and legal inconsistency of the measures; intellectual property rights; illicit trade risk; violation of trade agreements and subsidiary/proportionally principles ${ }^{4,16-19,34-}$ 35 . There is unequivocal evidence that these statements are intentionally designed to avoid or delay the implementation of effective measures to curb tobacco use $\mathrm{e}^{4,17,35}$. As such, the positions taken by the Portuguese Governments and policymakers deviate from public health science; do not represent the expressed will of the majority of EU/Portuguese citizens; and denote a clear violation of FCTC article 5.3 which binds the parties to protect public health policies from "commercial and other vested interests of the tobacco industry in accordance with national law ${ }^{2,}, 4$. Moreover, those positions overestimate economic issues upon public health and welfare, jeopardizing the fundamental right to health protection enshrined in Article 64 of the Portuguese Constitution ${ }^{36}$, in Article 35 of the Charter of Fundamental Rights of the $\mathrm{EU}^{37}$ and in the Treaty on the Functioning of the EU adopted in $2009^{38}$. Therefore, any positions counteracting these instruments seriously challenge Portugal's commitment to democracy, WHO and EU principles.

\section{CONCLUSIONS}

In sum, the Portuguese case clearly shows that tobacco industry interference at the national level, as well as poor capacity building, can undermine the impact of FCTC and EU regulations. It should also be emphasised that international cooperation, according to FCTC goals, should be a key strategy supporting countries with poor capacity building in order to advance TC in Europe.

The debate prior to the passing of the TPD through the EU parliament raised awareness of tobacco industry lobbying among decision-makers and civil society. This urges the need for effective measures that promote transparency during interactions with the tobacco industry to protect future legislations from attempts to weaken essential public health policies. Currently, advocacy activities and tools concerning transparency are under development, following the 9th Conference of the Parties to the FCTC which focused on Article $5.3^{39}$.

The aim is to timely denounce, publicly expose and effectively prevent tobacco industry interference on health 
policy, both at the national and international level. This should be objectively monitored.

\section{REFERENCES}

1. World Health Organization (WHO). European tobacco control status report 2013. Geneva, Switzerland: WHO; 2013.

2. World Health Organization. WHO Framework Convention on Tobacco Control. Geneva, Switzerland: WHO; 2003.

3. Joossens L, Raw M. The Tobacco Control Scale 2013 in Europe. Belgium: Association of European Cancer Leagues; 2014.

4. World Health Organization. Tobacco Industry Interference with Tobacco Control. Geneva, Switzerland: WHO; 2008.

5. Malone RE, Grundy Q, Bero LA. Tobacco industry denormalisation as a tobacco control intervention: a review. Tob Control. 2012;21:16270. doi:10.1136/tobaccocontrol-2011-050200.

6. Ravara SB. The role of healthcare professionals in tobacco control. [PhD thesis]. Covilha, Portugal: University of Beira Interior; 2015.

7. Willemsen MC, Nagelhout GE. Country differences and changes in focus of scientific tobacco control publications between 2000 and 2012 in Europe. Eur Addict Res. 2016;22(1):52-8. doi:10.1159/000381674.

8. Ravara SB, Miranda N, Calheiros JM, Berteletti F, Joossens L. Tobacco control progress in Portugal: The need for advocacy and civil society leadership. Rev Port Pneumol. 2014;20(6):289-92. doi: 10.1016/j.rppneu.2014.09.003.

9. Ravara SB, Castelo-Branco M, Aguiar P, Calheiros JM. Are physicians aware of their role in tobacco control? A conference-based survey in Portugal. BMC Public Health. 2014; 14:979 doi:10.1186/1471-2458-14-979.

10. Unknown. Corporate affairs work plan Spain and Portugal. 1990 May 14. Philip Morris. Available from: http://industrydocuments. library.ucsf.edu/tobacco/docs/jfkv0110 (accessed 9 Oct 2015)

11. Efza E. Against "the humanism of cigarettes": An analytical policy framework for tobacco corporate social responsibility in Europe. In: Association of European Cancer Leagues (ECL), editor. Proceedings of the 6th European Conference on Tobacco or Health (ECToH); 2014 Mar 28-29; Istanbul, Turkey. Brussels: Belgium; 2014. P. 57.

12. Sousa JCO. Avaliaço da implementaço das Polticas de Controlo de Tabagismo em Portugal e na Europa. Um estudo comparativo. [implementation of Tobacco Control policies in Portugal and Europe. A comparative study]. [Master dissertation]. Covilha, Portugal: University of Beira Interior; 2015.

13. Philip Morris International, Portugal. [Internet]. Responsabilidade e Mecenato. [Responsibility and Patronage]. Available from: http:// www.pmi.com/pt_pt/pages/homepage.aspx (accessed 9 Oct 2015)

14. World Health Organization. WHO Report on the Global Tobacco Epidemic, 2013. Enforcing bans on tobacco advertising, promotion and sponsorship. Geneva, Switzerland: WHO; 2013.

15. Directive 2014/40/EU of the European Parliament and of the Council of 3 April 2014 on the approximation of the laws, regulations and administrative provisions of the Member States concerning the manufacture, presentation and sale of tobacco and related products and repealing Directive 2001/37/EC.

Available from:http://ec.europa.eu/health/tobacco/docs/dir_ 201440_en.pdf (accessed 9 Oct 2015)

16. Savell E, Gilmore AB, Fooks G. How does the tobacco industry attempt to influence marketing regulations? A systematic review. PLoS One. 2014;9(2). e87389. doi: 10.1371/journal.pone.0087389.

17. Weishaar H. The Tobacco Epidemic and the Commercial Sector: Tobacco Industry Strategies to Increase Profits and Prevent
Regulation. In: Loddenkemper R, Kreuter M, editors. The Tobacco Epidemic. 2nd revised and extended edition. Prog Respir Res. Basel, Karger; 2015. doi: 10.1159/000369322.

18. Lei n37/2007, 14 de Agosto. Dirio da Repblica, 1.série -N. 156,14 de Agosto de 2007. [Tobacco law 2007].

19. Filho HC, Marques RF, Faria, PL. Dificuldades polticas, éticas e jurdicas na criaço e aplicaço da legislaço sobre lcool e tabaco: contributo para o desenvolvimento da investigaço em Direito da Sade Pblica. [Political, ethical and legal difficulties in the creation and enforcement of legislation on alcohol and tobacco: a contribution to the development of research in Public Health Law]. Rev Port Sade Pblica. 2010;28(2):205-18.

doi: 10.1136/tc.2008.028720.

20. Ravara SB, Castelo-Branco M,AguiarP, Calheiros JM. Compliance and enforcement of a partial smoking ban in Lisbon taxis: an exploratory cross-sectional study. BMC Public Health. 2013;13:134. doi: 10.1186/1471-2458-13-134.

21. Ravara SB, Miranda N, Calheiros JM. Towards a $100 \%$ smoke-free Portugal: No more delays. Rev Port Pneumol. 2014;20(5):282-3. doi: 10.1016/j.rppneu.2014.06.002.

22. Calheiros JM. Sad news from Portugal. Alliance Bulletin WHOFCTC. 2007, COP-2. 3 July:4.

23. Câncio F. Uma lei que as excepçes esfumam na prtica. [A law that goes up in smoke due to too many exemptions]. Dirio de Notcias [Internet]. 2008 Jan 19 Sect. Sociedade. Available from: http:// www.dn.pt/especiais/interior.aspx?content_id=1006620\&especial= Nova\%20Lei\%20do\%20Tabaco\&seccao=SOCIEDADE (accessed 9 Oct 2015)

24. Marques A. Fumar no avio: Scrates quis pagar multa, mas ninguém cobrou. [Smoking on board: Scrates wanted to pay a fine, but was not fined]. Dirio de Notcias [Internet]. 2008 Aug 6. Sect. Sociedade. Available from: http://www.jn.pt/PaginaInicial/Nacional/Interior. aspx?content_id=975555. (accessed 9 Oct 2015)

25. Assembleia da Repblica. Comisso de Assuntos Europeus. Projeto de Resoluço 622/XII/2. National Parliament. Parliamentary committee for European affairs. [Resolution project 622/XII/2]. Available from: http://www.parlamento.pt/ActividadeParlamentar/Paginas/ DetalheIniciativa.aspx?BID=37545 (accessed 9 Oct 2015)

26. Pereira H. Portugal trava restriçes ao tabaco. [Portugal blocks restrictions to tobacco]. Sol. [Internet]. 2013 Mar 13 Sect. Sociedade. Available from: http://www.sol.pt/noticia/69949/portugal-travarestri\%C3\%A7\%C3\%B5es-ao-tabaco\#close (accessed 9 Oct 2015)

27. Guerreiro C, Costa JF. Maços de tabaco dos Açores salvos. [Rescuing Azores' tobacco packages]. Sol. [Internet]. 2014 Jan 8 Sect. Sociedade. Portuguese. Available from: http://www.sol.pt/ noticia/96461/ma\%C3\%A7os-de-tabaco-dos-a\%C3\%A7ores-salvos (accessed 9 Oct 2015)

28. Council of the European Union - Employment, Social Policy, Health and Consumer Affairs. Hearing before the EU Tobacco Products Directive 2014 EPSCO Council - Legislative Deliberations. Friday, June 21, 2013 at 10.00. Availble from: http://video.consilium. europa.eu/webcast.aspx?ticket $=775-979-13060 \quad$ (accessed 9 Oct 2015)

29. Ravara SB, Miranda N, Morais A, Cunha Filho H, Calheiros JM. O Movimento de organizaçes no-governamentais (ONG) Portuguesas pelo Controlo do Tabagismo nos bastidores de Bruxelas e da Directiva dos Produtos de Tabaco. [The Portuguese Tobacco Control NGO Movement (NGO): on the backstage of the EU Tobacco Products Directive]. In: 10th Newsletter Oxigénio: 5-8. [Internet]. 
Portuguese Society of Pulmonology; 2014. Available from: http:// www.sppneumologia.pt/uploads/files/enewsletters/10\%C2\%AA edicao.pdf (accessed 9 Oct 2015)

30. European Commission. Attitudes of Europeans towards tobacco: Report. Special Eurobarometer 385. Brussels: TNS Opinion \& Social; 2012.

31. Ravara SB, Bragança F, Aguiar P, Calheiros JM. Support for tobacco control policies in Portugal: A population-based cross-sectional study in Portugal (preliminary data). Eur Resp J. 2013; 42(Suppl 57):s212.

32. Association of European Cancer Leagues, Cancer Research UK, Corporate Accountability International, Corporate Europe Observatory, European Public Health Alliance, French Committee for Tobacco Control et al. Joint Open Letter to President of European Parliament. Philip Morris lobbying activities on the Tobacco Products Directive. Brussels; 1 October 2013. Available from: http://www.epha.org/a/5829 (accessed 9 Oct 2015)

33. Doward J. Tobacco giant Philip Morris 'spent millions in bid to delay EU legislation'. The guardian. 2013 September 7;23.26. Available from: http://www.theguardian.com/business/2013/sep/07/ tobacco-philip-morris-millions-delay-eu-legislation (accessed 9 Oct 2015)

34. Costa H, Gilmore AB, Peeters S, McKee M, Stucker D. Quantifying the influence of the tobacco industry on EU governance: automated content analysis of the EU Tobacco Products Directive. Tob Control. 2014; 23(6): 473-8.

35. doi: 10.1136/tobaccocontrol-2014-051822

36. Mandal S, Gilmore AB, Collin J, Weishaar H, Smith K, McKee M. Block, amend, delay: tobacco industry efforts to influence the European Union's Tobacco Products Directive (2001/37/EC). Brussels: Smokefree Partnership/Cancer Research UK. Available from: http://www.smokefreepartnership.eu/sfp-reports (accessed: 9 Oct 2015)

37. Constituiço da Repblica Portuguesa.[Constitution of the Portuguese Republic]. Available from: http://www.parlamento.pt/parlamento/ documents/crp1976.pdf (accessed: 9 Oct 2015)

38. Charter of Fundamental Rights of the European Union. Available from: http://www.europarl.europa.eu/charter/pdf/text_en.pdf (accessed: 9 Oct 2015)

39. Consolidated version of the treaty on the functioning of the European Union. Available from: http://eur-lex.europa.eu/legalcontent/EN/ TXT/?uri=celex:12012E/TXT (accessed: 9 Oct 2015)

40. Conference of the Parties to the FCTC. Implementation of Article 5.3 of the WHO FCTC: evolving issues related to interference by the tobacco industry. Geneva, Switzerland: WHO; 2014.

CONFLICT OF INTEREST The authors have completed and submitted the ICMUE Form for Disclosure of Potential Conflicts of Interest and none were reported.

FUNDING

There was no source of funding for this research.

PROVENANCE AND PEER REVIEW

Not commissioned; externally peer reviewed 